- summarize/ paraphrase; - reflect on what has been learned; - find relationships/mapping; - associate new information with old; - seek feedback; - interpret text; - make connections; - confirm predictions; - journals; - reading logs; - note-taking.

Here we would like to give some recommendations

a) for all teachers to:

- Read more and take courses about how to teach reading in a best way.

- Know the three main stages of reading and the strategies of each stage. Then try to apply what they know about them:

b) forallStudentsto:

- Take care of reading and try to improve their skills in reading.

- Do not depend on their teachers all time but they should try to read and read to become good readers.

When teachers apply these stages carefully, students learn how to use them in different texts they read without teacher. Also, encourage student to read different kinds of materials.

Conclusion.Reading develops students' intelligence. It helps develop their memory, will, imagination. Students become accustomed to working with books, which in its turn facilitate unaided practice in further reading. The content of texts, their ideological and political spirit influences students. We must develop in students such qualities as honesty, devotion to and love for our people and the working people of other countries, the texts our students are to read must meet these requirements. Reading ability is, therefore, not only of great practical, but educational, and social importance, too.

Reading is not only an aim in itself; it is also a means of learning a foreign language. When reading a text the student reviews sounds and letters, vocabulary and grammar, memorizes the spelling of words, the meaning of words and word combinations, he also reviews grammar and, in this way, he perfects his command of the target language. The more the student reads, the better his retention of the linguistic material is. If the teacher instructs his students in good reading and they can read with sufficient fluency and complete comprehension he helps them acquire speaking and writing skills as well. Reading is, therefore, both an aim to be attained and a means to achieve that aim

\title{
References:
}

1. Allwright D.The Interaction Hypothesis.Language Learning in Formal and Informal Context.Cambridge University Press, 1998.

2. Brown G. Listening to Spoken English. Cambridge University Press, 1999.

3. Davies P., Pears E. Success in English Teaching. Oxford University Press, 2000.

4. Florence D. Introducing Reading. Penguin English, 1998.

5. Christine N. Teaching Reading Skills in foreign Language, Heineman, 2000.

6. Nunun D.The Nature of Approaches and Methods.Oxford University Press, 2001. References:

1. Ollrait D. Gipoteza vzaimodeistvia.Izuchenie iazyka v formälnom i neformälnom kontekste [The Interaction Hypothesis.Language Learning in Formal and Informal Context]// Izdatelstvo Kembrijskogo universiteta, 1998.

2. Braun G. Prosluşivanie razgovornogo angliskogo iazyka.[ Listening to Spoken English.] İzdatelstvo Kembrijskogo universiteta, 1999.

3. . Devis P., Pirs E. Uspeh v prepodavanii angliskogo iazyka.[ Success in English Teaching] İzdatelstvo Oksfordskogo universiteta, 2000.

4. $\quad$ Florens D. Znakomstvo s Chteniem. [Introducing Reading]Penguin English, 1998.

5. Kristina N. Obuchenie navykam chtenia na inostrannom iazyke, [Teaching Reading Skills in foreign Language]Haineman, 2000.

6. Nunun D. Priroda podhodov i metodov.[ The Nature of Approaches and Methods]İzdatelstvo Oksfordskogo universiteta, 2001.

М НТИ Р17.07.41

https ://doi.org/10.51889/2020-4.1728-7804.14

\author{
Zhetpisov S. $^{1}$ \\ ${ }^{1}$ Abylai Khan Kazakh University of international relations and world languages, \\ Almaty, Kazakhstan
}

\section{INTERFERENCE OF LANGUAGES IN KAZAKHSTAN}

\section{Abstract}

The article examines the issues of Korean-Russian-Kazakh trilingualism since 1937 from the moment of the forced resettlement of Koreans from the Far East to Kazakhstan and Central Asia. The study examined the functioning of the Korean language for 80 years, Korean living in Kazakhstan. The factors that determined the interaction of the three languages are primarily the daily communication of Koreans with Kazakhs, Russians and other peoples of Kazakhstan. The political factor also plays an important role, since the majority of the non-Kazakh population was resettled to Kazakhstan as a result of state policy. The geographical factor, compactness of settlement, linguistic contacts of Koreans and Kazakhs with other peoples, 
school education, the presence of an intermediary language, the media, as well as the language policy pursued in different periods of the country's history are also important.

Keywords: Korean-Russian bilingualism, Korean-Kazakh bilingualism, Korean-Russian-Kazakh trilingualism, language policy, spheres of language functioning

\author{
Жетпісов C.H. ${ }^{l}$ \\ ${ }^{1}$ Абылай хан атындавы Қазақ халыққаралық құатынастар және әлем тілдері университеті, \\ Алматы, Қазақстан
}

\title{
КАЗАҚСТАН ТІЛДЕРІНІН ӨЗАРА ӘСЕРІ
}

\begin{abstract}
Аңъдатпа
Мақалада 1937 жылдан бастап корейлерді Қиыр Шығыстан Қазақстан мен Орта Азияға күштеп қоныс аударған сәттен бастап корей-орыс-қазақ үштілдігінің мәселелері қарастырылады. Үш тілдің өзара байланысын анықтайтын факторлар, ең алдымен, корейлердің қазақтармен, орыстармен және Қазақстанның басқа халықтарымен күнделікті байланысы. Саяси фактор да маңызды рөл атқарады, өйткені мемлекеттік саясаттың нәтижесінде қазақ емес халықтың көп бөлігі Қазақстанға қоныс аударды. Географиялық фактор, қоныстану ықшамдығы, корейлер мен қазақтардың басқа халықтармен тілдік байланыстары, мектептегі білім, делдал тілдің болуы, бұқаралық ақпарат құралдары, сондай-ақ ел тарихының әртүрлі кезеңдерінде жүргізілген тіл саясаты да маңызды.
\end{abstract}

Түйін сөздер: корей-орыс қос тілділігі, корей-қазақ қос тілділігі, корей-орыс-қазақ үштілділігі, тіл саясаты, тілдің қызмет ету салалары

Жетписов C.H. ${ }^{l}$

${ }^{1}$ Казахский университет международных отношений и мировых языков, имени Абылай хана, Алматы, Казахстан

\section{ВЗАИМОВЛИЯНИЕ ЯЗЫКОВ КАЗАХСТАНА}

\begin{abstract}
Аннотаичя
Статья рассматривает вопросы корейско-русско-казахского трехъязычия с 1937 г. С момента насильственного переселения корейцев с Дальнего Востока в Казахстан и Среднюю Азию. К факторам, обусловившим взаимодействие трех языков, относятся прежде всего повседневное общение корейцев с казахами, русскими и другими народами Казахстана. Большую роль играет также политический фактор, так как большинство неказахского населения было переселено в Казахстан в результате политики государства. Имеет значение также географический фактор, компактность расселения, языковые контакты корейцев и казахов с другими народами, школьное образование, наличие языка-посредника, средств массовой информации, а также языковая политика, проводимая в разные периоды истории страны.
\end{abstract}

Ключевые слова: корейско-русское двуязычие, корейско-казахское двуязычие, корейско-русско-казахское трехъязычие, языковая политика, сферы функционирования языков

Introduction. The emergence of the Korean-Russian-Kazakh trilingualism is due to a number of reasons, and, first of all, the wide communication of Koreans with Kazakhs, Russians and other peoples of Kazakhstan. The political factor also plays an important role, since the majority of the non-Kazakh population was resettled to Kazakhstan as a result of state policy. The compactness of settlement, school education, the presence of an intermediary language and the media are also important.

The political factor. In the autumn of 1937, a mass migration of Koreans to the regions of Central Asia and Kazakhstan began. The reasons for this act of the government can be divided into two groups: foreign policy and domestic. The first group includes: I) the annexation of Korea in 1910 and its declaration as a Japanese protectorate; 2) Japanese intervention in the Far East in 1918-22; 3) the Manchu incident of 1931 and the formation of Manchukuo; 4) the adoption in 1936 by the Japanese government of the "Directive for the national defense of the empire," in which the USSR was declared enemy No. I; 5) the signing of the Japanese-German anti-Comintern pact in July 1936; 6) armed clashes on the border with China in 1937. Domestic political reasons are due to the policy of the state, which is characterized by distrust of all national minorities.

Methodology.The resettlement to Central Asia and Kazakhstan, whose area was dozens of times larger than the territory of the Far Eastern Territory, meant that groups of the Korean population were scattered in new regions. The placement of immigrants in Kazakhstan had economic goals as well: the deficit of labor resources, which arose as a result of the famine of 1931-33, when about 2 million people died and migrated, was partially filled. In 1939, the total number of the Korean population in the republic was 97296 people, settled mainly in the southern regions.

The prevalence of the Russian language is due to the predominance of the Russian population in the republic for almost 60 years, the high prestige of the Russian language, the large proportion of the non-indigenous population, as well as the language policy that contributed to the introduction of the Russian language into all spheres of society, and finally, the long 
language tradition that existed for many decades. The influence of these factors has been significantly weakened in recent years, and this leads to a linguistic reorientation of the population, primarily Kazakh, which less often uses the Russian language in communication with representatives of related peoples living in Kazakhstan: Uzbeks, Tatars, Kyrgyz, Turks, etc.

Results.However, at present the Russian language is the most common language in Kazakhstan, ousted most other languages from many spheres of functioning; most of the non-indigenous peoples of the republic are practically monolingual and use only Russian. At the same time, the demographic base of the Russian language is rapidly shrinking due to a decrease in the proportion of Russians in the country's population and the final transition to schooling in the Kazakh language: in 2020, $89 \%$ of schoolchildren study in Kazakh schools.

Kazakh language. The period until 1991 was very difficult for the Kazakh language, since all this time it was exposed to unfavorable factors: a two-fold change of the alphabet, the policy of language fusion, the enormous influence of the Russian language, the action of unfavorable demographic factors. All this led to a narrowing of the spheres of functioning of the Kazakh language. Currently, the Kazakh language performs the following functions: I) the function of communication between native speakers in most spheres of activity; 2) the function of communication between native speakers within the republic; 3) the function of the language of instruction. In this area, the Kazakh language was significantly inferior to Russian; Thus, in 1989, the Kazakhs had 1.5 million school-age children, and 931 thousand children (62.1\%) studied in Kazakh schools. In the 2005-2006 academic year, the situation changed: out of 1,911,601 Kazakh children, 1,548,246 studied in Kazakh schools (81\%). Children of other nationalities number 377,502; of them 254559 people study in Russian schools (67.4\%), in Kazakh schools - 21000 people (5.6\%), in national schools 101952 people (27\%). The teaching of natural science subjects in English adopted in Kazakhstan will push the Russian language to the sidelines, and for the Russian population this is a great shock, clearly showing that they are no longer the dominant nation of a subordinate union republic, but only one of the national diasporas of an independent country. This initiative in the field of education makes Russians think about the future of their children, about how they should preserve their ethnocultural appearance in conditions of isolation from their mother's culture, and this concern is felt more and more every year. The emigration of recent years confirms that a significant part of the non-Kazakh population does not associate their prospects with Kazakhstan.

In 1976, out of 47 universities and 208 secondary specialized educational institutions in the Kazakh language, individual subjects were taught in 23 universities and 18 pedagogical colleges; until 1989 there was not a single technical school with the Kazakh language of instruction. In 1989, when the Law on Languages was adopted, guaranteeing, among other things, the continuity of the language of instruction, four times more children began to study in the first grades of Kazakh schools than in 1988. The role of the Kazakh language as a language of instruction is constantly increasing, since it has state support and the largest demographic base of the country; 4) the function of the language of fiction and socio-political literature; the development of this function is fairly objectively shown by the following data: in 1988, out of the titles of books and brochures, a little more than a quarter was given to literature in the Kazakh language, and the circulation of almost $40 \%$ consists of the circulation of Kazakh books and brochures, which is quite consistent with the variety of interests and specific weight different peoples in the population of the republic. This means that the Kazakh language quite intensively performs the function of the language of fiction and socio-political literature; 5) the function of the language of science; this function of the Kazakh language has not received proper development. Out of 31 scientific divisions of the National Academy of Sciences of the Republic of Kazakhstan, only two - the Institute of Linguistics and the Institute of Literature and Art - part of the research work is conducted in the Kazakh language. In the rest of the institutes, as well as in the universities of the republic, practically all research is conducted in Russian. This is especially true for the technical branches of science, where there are no works in the Kazakh language at all. Currently, Kazakhstan is in the position of developing countries, where national languages are declared state ones, however, in the fields of science and technology, English and French are used, since the languages of these states do not yet have developed scientific and technical terminology. Therefore, for the Kazakh language, the development of scientific and technical terminology is a priority task. Work in this direction is already underway: the Kazakh language expands its function of the language of school and university education; 6) the function of the language of periodicals; the Kazakh language quite actively performs this function, since the number of students in Kazakh schools is growing, and the number of students in Russian schools is decreasing; 7) the function of the language of various spheres of social and political life; the Kazakh language freely performs this function; 8) the function of the language of interethnic communication; the Kazakh language performs this function in a rather limited volume, mainly in rural areas with a large predominance of the Kazakh population. Obviously, it will take a long period of time for the use of the Kazakh language as a language of interethnic communication to become the norm; 9) the function of the state language; the legislative granting of the state status to the Kazakh language sharply increased its role in the life of the country. This led to the fact that representatives of other peoples, especially Russians, began to fear for their identity. The habit of living in monolingual comfort often interferes with Russians in everyday life and is one of the sources of social tension in areas with a significant concentration of the Russian population. The ongoing outflow of the Russian-speaking population is, in fact, a rejection of the new social position and a manifestation of the choice of their identity. The illusion that the participation of Kazakhstan in integration associations with Russia will allow the Russians living in it to preserve their ethnocultural peculiarity have practically disappeared. Kazakhstan is de facto breaking out of a single educational and cultural space, which Russia tried to preserve after the collapse of the USSR, and this accordingly raises the question: to leave or stay? Time will show which groups of the population of Kazakhstan will switch to the Kazakh language, and which will prefer emigration. The Korean population is fully Russified, but racially closer to Kazakhs than Russians. Considering that linguistic discomfort is easier to overcome than xenophobia that is typical for Russia, then, most likely, the majority of Koreans will remain in Kazakhstan. 
Intrastructural development of the Korean language.

The language of Kazakh Koreans bears the imprint of the strongest influence of the Russian language, as well as, albeit to a lesser extent, the influence of the Kazakh language. The stronger influence of the Russian language is explained by the prescription of the Korean-Russian contacts. The influence of the Russian and Kazakh languages practically did not affect the grammatical structure of the Korean language. Only three facts of deviation from the grammar of the literary Korean language were found: the use of the particle of men as a comparison, the imposition of a three-digit counting method, and the morphological construction of the adjective serok-serone / new / following the pattern of adjectives in the Turkic languages zhap-jana (super-new).

As far as vocabulary is concerned, the language of the Koreans of the CIS is a rather interesting phenomenon. Most Koreans in this group come from the northern part of the Korean Peninsula, so their language is represented by the dialect of North Hamgyong Province. The North Hamgen dialect can be divided into three subgroups: Yujup, which is widespread in the northern part of the Korean Peninsula on the border with the RSFSR and the DPRK, Saup (Gyeongsong, Myeongchon, Kilju and Haxon provinces), and Myusan on the western border with China. The Yujup subgroup is of particular interest not only from a geographical, but also from a historical point of view, since in the beginning this region was inhabited by the Jurchens, and from the $15^{\text {th }}$ century AD. Began to be settled by immigrants from the south of the peninsula and political refugees from various provinces of Korea. Therefore, in the language of the Koreans of the CIS, there can be found not only archaisms that are no longer used in the language of the Korean peninsula, but also Jurchen words that have been preserved in the language.

The Russian language also had a huge influence on him, and after the resettlement to Kazakhstan, the Korean language was also influenced by the Kazakh language. The influence of the Russian and Kazakh languages had a particularly strong effect on the vocabulary; at the same time, different layers of vocabulary react differently to contacts with other languages and borrow Russian and Kazakh words with different intensity. The areas of vocabulary most impenetrable for foreign words turned out to be the terms of kinship, the names of parts of the body, natural phenomena, religion, etc.:

- terms of relationship; they may differ from the literary ones: ajebi (instead of: ajessi) - uncle; ame (instead of: halmoni) - grandmother; ankkan (instead of: ankhe) - wife; harabe (instead of: harabodzhi) - grandfather; namjon (instead of: namphyon) - husband; orebi (instead of: tonsen) - younger brother, etc .; however, most of the terms in the language of the Soviet Koreans and the language of the Korean Peninsula are the same. The absence of foreign language borrowings is explained by the extraordinary diversity of the terminology of kinship, which, like the Kazakh, is much richer than the Russian one and satisfies all the needs: hyenja is an older brother (in relation to a brother); oppa - older brother (in relation to sister); nui - younger sister, nunim - older sister; samcheon - maternal uncle; khynabodji - uncle (elder brother of father or mother); chagynabodzhi - uncle (younger brother of father or mother); imo - aunt (from the mother's side); komo - aunt (from the father's side); saun - son-in-law (daughter's husband); mebu, mehyon - son-in-law (husband of an older sister); meje - son-in-law (husband of a younger sister); myonuri - daughter-in-law (son's wife); hyonsu - daughter-in-law (brother's wife);

-names of body parts; they can also differ from the literary ones: agari (instead of: un) - mouth; santhon (instead of: olgul) - face; kundi (instead of: nopchoktari) - hips; ime, imandegi (instead of: ima) -lob, etc. For the most part, however, they coincide with literary terms: mori - head, sleep - hand, finger - leg, okke - shoulder, sonkarak - finger, pe - belly, tyn back, etc .;

-names of natural phenomena; the lack of borrowing in this area is explained by the development of this terminology, due to the centuries-old traditions of agriculture. The names of natural phenomena coincide with the terms of the literary language; they are distinguished by their wealth, often have synonyms: nalssi, nalsa, ilgi - weather; kamyl, hanchkhon, hanbal - drought; urve, sonak - thunder; pi - rain; kulgyn pi - heavy rain; karan pi - fine rain; phokphunu - thunderstorm; honsu flood; tephun, phokphun - typhoon;

-religious vocabulary; in this sphere of the functioning of the language, the Korean language did not have any contacts with either Russian or Kazakh, so there are no borrowings from these languages in it, and all vocabulary is original or borrowed from the Chinese language: son'in - holy, Tansik - post, Kido - prayer, chun - Buddhist monk, etc.

In other spheres of vocabulary, there are borrowings, the number of which is not the same and depends on the subject:

-the sphere of everyday life; a significant number of Russian and Kazakh borrowings are found here: car, sugar, bazaar, vacation, construction, carrots, teahouse, plane tree, dumplings, burqa, noodles, aul, etc. It should be noted that if words are borrowed from the Kazakh language that denote concepts that are new to the Korean language, such as akyn, ayran, kurt, saxaul, etc., then words that have equivalents in the Korean language can be borrowed from Russian: (cor .: illyeongam); bucket (cor .: multhon, pakketsy) fork (cor .: hokhy), etc .; the use of Russian words speaks of the linguistic assimilation of the majority of Koreans and the strongest influence of the Russian language on the speech of Koreans when they use their native language; even the Turkic words are partially borrowed through the Russian language: skullcap, yurt, plane tree, kumys, noodles, etc .;

-lexics of folk spiritual culture; in this area, a significant number of borrowed words are found, mainly from the Russian language: competition, interview, essay, button accordion, script, violin; the number of borrowings from the Kazakh language is constantly growing: dombra, hashar (collective assistance), doira (tambourine), syrmak, alasha (palace). Here the situation is the same: words are often borrowed from the Russian language that have equivalents in Korean, from Kazakh - only denoting new concepts: tekemet (koshma), dastarkhan (tablecloth, set table), aitys (akyns competition); 
- written traditions; Soviet Koreans managed to preserve their written language, and this significantly weakened the Russification of the language, since the borrowed words were transferred to the Korean script and at the same time underwent phonetic transformations in accordance with the norms of the Korean language. Therefore, the literary language of Soviet Koreans - the language of Lenin Kichi and collections of stories and poems published in Almaty - is identical to the literary language of the Korean peninsula, with the exception of a small number of borrowings that distinguish them from each other and are mainly related to social and political vocabulary.

Over the past eight decades, there have been significant changes in the phonetic processing of loan words. The tendency to preserve their sound form began to prevail. The following phonetic substitutions have disappeared: I) the substitution of ph for ph: instead of phartukkha, phylleita, aprukhy and flute began to speak; 2) hissing w, $\mathrm{z}$ and w began to persist, which were previously replaced by s: buryzhua (it was purysua) - bourgeois; collective farms (there were collective farms) - collective farm; shashikhi - checkers; 3 ) the combination of $\mathrm{j}$ is retained, which was previously replaced by c: jumpers - jumper (it was: cement); burqa; 4) soft $\mathrm{n}$ began to be preserved: kkoniki (was: kkonkki) - skates; 5) at the beginning of the word, $\mathrm{p}$ and $\mathrm{b}$ began to be preserved, previously replaced by 1 and p: rubyly (was: lubylli) - ruble; racketta (lacchetta) - rocket; bylokhy (dyllokhy) - block; byrigada (pyrigada) - brigade; 6) began to remain in, which was replaced by the letter p: buses (aptobuses) - a bus; state farms (ssophoses) - state farm; 7) the combination of consonants zk is preserved: blouse (dyllusikha) - blouse.

Such changes indicate the continuing impact of the Russian language on Korean and the Russification of the Korean language.

Language contacts and their consequences. The Korean language has lost most of its social functions: the function of communication between native speakers in all areas of activity; communication between native speakers within the republic; language of instruction; language of science. The remaining functions are extremely narrowed and cover a very small part of the population; these include: the function of the language of family and everyday communication; language of fiction and socio-political literature; language of various spheres of social and political life. Thus, the situation with the Korean language can be characterized as the completion of the language assimilation of the Korean population.

Conclusion. The Kazakh language also gives way to the Russian language. A significant part of Kazakhs use the Russian language, although all spheres of functioning of the Kazakh language have been preserved.

The Russian language has not lost any social functions, but has significantly narrowed the scope of its use, mainly due to the fact that graduates of Kazakh schools are already completely Kazakh-speaking, although in the field of interethnic communication, Russian is almost always used. In the field of science, the situation is approximately the same. Obviously, the introduction of the Kazakh language into these spheres of communication is a rather long process, although the demographic development of the country and state policy will undoubtedly ensure its implementation.

Thus, the current state of the languages of the peoples of our country is the result of a purposeful Russification policy pursued by the USSR for 70 years. The new policy gives hope for the elimination of its consequences. It provides real assistance in the development of languages, primarily of large nations, since in the regions of their residence the national and linguistic environment has been preserved to one degree or another. As for the small peoples, the activity in relation to their languages is largely impeded due to the lack of social order for them. However, the opening of free courses, Korean language groups in universities, the organization of national cultural centers, an increase in the circulation of published literature, the opening of national theaters, etc. allows anyone to learn the language and work with it in organizations where it is in demand. The processes taking place in the linguistic life of the country show the great importance of linguistic problems in solving the national question, therefore they must be treated with great attention and caution, since they affect the interests of millions of people. In Kazakhstan, they understand that all people want to live in their descendants: children, grandchildren, greatgrandchildren, in their culture and their civilization. Justice requires everyone to have the right to do so. Justice is an instinct for collective survival, projected onto the plane of social relations and moral ideas. An unjust state cannot be strong and durable.

\section{References:}

1 Anosov S.D. Koreans in the Ussuri region. Khabarovsk-Vladivostok. I928. C.II.

2 2.Dzharylgasynova R.Sh. "Culture and life of Koreans of the state farm" Raushan "of the Kungrad region of the Karakalpak ASSR”. M., 1960.

3 DzharylgasynovaR.Sh. "On the issue of cultural rapprochement of the Koreans of the Uzbek SSR with neighboring peoples (Traditional and new in the economy and material culture)." Soviet ethnography. M., 1966, No. 5.S.3-14;

4 DzharylgasynovaR.Sh. "Traditional and new in the family rituals of Koreans in Central Asia." History, archeology and ethnography of Central Asia. M., 1968. S. 343-349;

5 DzharylgasynovaR.Sh. "Anthroponymic processes among Koreans of Central Asia and Kazakhstan. Personal names in the past, present, future. "M., 1970. C. I39-I49;

6 Dz5harylgasynova R.Sh. "New in the culture and life of Koreans in Central Asia and Kazakhstan (on the example of the rural population)”. Soviet ethnography. M., 1977. No. 6.C.59-70;

7 DzharylgasynovaR.Sh. "To the characteristic of the modern anthroponymic model of Koreans living in rural areas of the Uzbek SSR." Onomastics of Central Asia. M., 1978. S.203-205;

8 DzharylgasynovaR.Sh. "The main tendencies of ethnic processes among Koreans in Central Asia and Kazakhstan." Ethnic processes among the national groups of Central Asia and Kazakhstan. M., 1980, p. 431. 
9 IonovaYu.V. "Among the Koreans of Central Asia” (Brief reports of the Institute of Ethnography. XXXY 111. M., 1963. S. 23-34).

10 Kim Seunghwa. Essay on the history of Soviet Koreans. Alma-ata, 1965, p. 60.

11 KoSonmu, "Koreans in Soviet Central Asia”, Helsinki, 1987. (in English).

12 Levin "Field research of the Institute of Ethnography in 1946". Soviet ethnography. M., 1946.

13 Pak B.D. The liberation struggle of the Korean people on the eve of the First World War. M., 1979.

14 Petrov A.N. Koreans and their importance in the economy of the Far East. North Asia, 1929, No. 1 1963.

15 Hegai M.A "Lexical borrowings from the Russian language in Korean translations". Abstract of Ph.D. thesis. M.,

\section{References:}

1. Anosov S. D. Koreisy v Ussuriskom krae.[ Koreans in the Ussuri region. Khabarovsk-Vladivostok.] HabarovskVladivostok. 1928. C. II.

2. .Jarylgasynova R.Sh "Kültura i byt koreisev sovhoza" Rauşan "Kungradskoi oblasti Karakalpakskoi ASSR". ["Culture and life of Koreans of the state farm" Raushan "of the Kungrad region of the Karakalpak ASSR"]M., 1960.

3. DzharylgasynovaR.Sh. "K voprosu o külturnom sblijenii koreisev Uzbekskoi SSR s sosednimi narodami (tradisionnoe i novoe v ekonomike i materiälnoi külture).” Sovetskaia etnografia. ["On the issue of cultural rapprochement of the Koreans of the Uzbek SSR with neighboring peoples (Traditional and new in the economy and material culture)." Soviet ethnography.]M., 1966, № 5.S. 3-14;

4. DzharylgasynovaR.Sh. "Tradisionnoe i novoe v semeinyh ritualah koreisev v Senträlnoi Azii". İstoria, arheologia $i$ etnografia Senträlnoi Azii. ["Traditional and new in the family rituals of Koreans in Central Asia. ” History, archeology and ethnography of Central Asia.]M., 1968. S. 343-349;

5. DzharylgasynovaR.Sh. "Antroponimicheskie prosesy sredi koreisev Senträlnoi Azii i Kazahstana. Lichnye imena v proşlom, nastoiaşem, buduşem ".["Anthroponymic processes among Koreans of Central Asia and Kazakhstan. Personal names in the past, present, future. "] M., 1970. C. I39-I49;

6. Dz5harylgasynova R.Sh. "Novoe v külture i jizni koreisev v Senträlnoi Azii i Kazahstane (na primere selskogo naselenia)". Sovetskaia etnografia.[. "New in the culture and life of Koreans in Central Asia and Kazakhstan (on the example of the rural population)”. Soviet ethnography] M., 1977. № 6.S. 59-70;

7. DzharylgasynovaR.Sh "K harakteristike sovremennoi antroponimicheskoi modeli koreisev, projivaiuşih v selskoi mestnosti Uzbekskoi SSR". Onomastika Srednei Azii.[ "To the characteristic of the modern anthroponymic model of Koreans living in rural areas of the Uzbek SSR. '] M., 1978. S. 203-205;

8. DzharylgasynovaR.Sh. "Osnovnye tendensii etnicheskih prosesov sredi koreisev v Senträlnoi Azii i Kazahstane." ["The main tendencies of ethnic processes among Koreans in Central Asia and Kazakhstan. "] Etnicheskie prosesy sredi nasionälnyh grupp Senträlnoi Azii i Kazahstana. M., 1980, s. 431.

9. İonova İ. V. "Sredi koreisev Senträlnoi Azii" [ "Among the Koreans of Central Asia”] (Kratkie doklady Instituta etnografii. 111 111. M., 1963. S. 23-34).

10. Kim Syn Hva. Ocherk istorii sovetskih koreisev.[ . Essay on the history of Soviet Koreans] Alma-ata, 1965, s. 60.

11. KoSonmu, "Koreisy v sovetskoi Senträlnoi Azii", [ "Koreans in Soviet Central Asia",] Helsinki, 1987. (na angliskom iazyke).

12. Levin "Polevye issledovania Instituta etnografii v 1946 godu".["Field research of the Institute of Ethnography in 1946”.] Sovetskaia etnografia. M., 1946.

13. Pak B. D. Osvoboditelnaia börba koreiskogo naroda nakanune Pervoi mirovoi voiny[The liberation struggle of the Korean people on the eve of the First World War]. M., 1979.

14. Petrov A. N.Koreisy i ih znachenie v ekonomike Dälnego Vostoka.[ Koreans and their importance in the economy of the Far East. North Asia,] Severnaia Azia, 1929, № 1

15. Hegai M. A "Leksicheskie zaimstvovania iz ruskogo iazyka v koreiskih perevodah".[ "Lexical borrowings from the Russian language in Korean translations"] Avtoreferat doktorskoi disertasii. M., 1963. 